\title{
IN SEARCH OF A REPLACEMENT FOR ECONOMIC JOURNALS: THE DIFFUSION OF POLITICAL ECONOMY IN CULTURAL REVIEWS IN THE LIBERAL AGE IN SPAIN, 1868-1914*
}

\author{
JAVIER SAN-JULIAN-ARRUPE \\ University of Barcelona $^{\mathrm{a}}$
}

\begin{abstract}
The foundation of specialised economic journals was one of the main traits in the process of institutionalisation of political economy in $19^{\text {th }}$ century Western Europe. Spain joined this trend at an early stage and in the 1850s and 1860 s some specialised, albeit ephemeral, journals sponsored by the liberal school of economic thought - the Economist School - emerged. However, when these reviews ceased publication, Spanish economists lacked specialised periodicals as an outlet for their contributions. Miscellaneous literary reviews addressing a wider audience represented an alternative for the diffusion of economic papers into educated society, sharing space with many other scientific and literary disciplines. This paper analyses the presence of texts on political economy in four of the most important of these reviews in the period 1868-1914, when Spain lacked economic publications. In spite of not being specialised reviews, these publications played a central role in the process of diffusion and popularisation of political economy as a valuable field of knowledge, acting as a good substitute for specifically economic journals.

* Received 6 May 2014. Accepted 5 January 2015. Research for this article has benefitted from an Accueil Pro scholarship of the CMIRA Programme awarded by the government of the Région Rhône-Alpes. The author is grateful for the comments and criticism of two anonymous referees, as well as those of members of Laboratoire Triangle UMR 5206, Université Lumière Lyon 2. Financial support has also been provided by the research project ECO2012-39169-C03-03 (Ministry of Science, Spain), the research groups GRGDEP (XREPP) and SGR 1345 (Gov. of Catalonia) and the Centre d'Estudis Antoni de Capmany. The author also thanks the support of the Department of Economic History and Institutions of the University of Barcelona. Usual disclaimer applies.

a Department of Economic History and Institutions, Faculty of Economics and Business Administration, Av. Diagonal 690,08034 Barcelona, Spain. jsanjulian@ub.edu
\end{abstract}


Keywords: economic journals, political economy, economic institutionalisation, intellectual history, sociology of economics.

JEL Codes: A11, A14, B00, N01

\section{RESUMEN}

La creación de revistas especializadas en economía es uno de los rasgos importantes del proceso de institucionalización de la economía política en Europa en el siglo XIX. En España algunas revistas especializadas de breve vida vinculadas a la Escuela Economista aparecieron en las décadas de 18501860. Desde su cierre hasta la segunda década del siglo XX no existieron revistas específicamente económicas en España. Las publicaciones periódicas de carácter cultural y literario ofrecieron una alternativa para la difusión de artículos sobre cuestiones económicas, compartiendo espacio con otras disciplinas científicas, literarias y sociales. Este artículo analiza la presencia de textos económicos en las más importantes de estas revistas entre 1868 y 1914. La conclusión es que, a pesar de no ser un marco especializado, estas publicaciones jugaron un papel importante en el proceso de difusión y popularización de la economía como un valioso campo de conocimiento, constituyendo un buen sustituto para la ausencia de publicaciones especializadas.

Palabras clave: revistas económicas, economía política, institucionalización de la economía, historia intelectual, sociología de la economía.

\section{INTRODUCTION}

Literature has stressed the crucial role that specialised journals played in the development, diffusion and consolidation of political economy as a new field of knowledge in the $19^{\text {th }}$ century. Henderson has pointed out that «journals and societies are institutions, which foster the production of new kinds of knowledge and the new methods of constructing such knowledge» (Henderson 1996, pp. 186-187). In a similar line, Costa noted that structured journals were an essential instrument in the constitution of specialised branches of knowledge in the $19^{\text {th }}$ and $20^{\text {th }}$ centuries (Costa 1996, p. 128). Focusing on the field of economics, according to Albert, the press was the instrument of popularisation of economic ideas and the arena where economic doctrines and interests collided. The emergence of specialised journals was the opportunity for economic ideas to be more detailed and independently presented (Albert 1996, p. 7). Literature on the role of 
economic journals in the spread of political economy in the $19^{\text {th }}$ century in the Western world is plentiful; much of it produced in the framework of the general analysis of the institutionalisation of economics. Early works on British and American economic journals were delivered by Stigler (1965), Fetter (1965) and Coats (1971). In the 1990s interest in this topic boomed ${ }^{1}$.

Journals specifically devoted to economic matters emerged in Europe in the first half of the $19^{\text {th }}$ century. Until the last decades of the century, these were in general pre-professional, usually the organs of schools of economic ideas, sponsoring particular political or philosophical doctrines (Faucci 1996, p. 118). This was the case of the Journal des économistes (founded in 1841) and L'économiste français (1873) in France, the reviews of the Economist School in Spain (1850s and 1860s), Jahrbuch für Gesetzgebung linked to the Historical School in Germany (1871), and the Italian reviews founded in the 1870 s by orthodox liberals (Economista, 1874) and sympathisers of chair socialism (Giornale degli economisti, 1875) ${ }^{2}$. Economic journals appeared in Britain late, in a much more specialised fashion, with the foundation of the Economic Review and Economic Journal in $1891^{3}$. Strict economic professional journals did not emerge in Europe until the end of the century, when the professionalisation of the discipline strengthened: Revue d'économie politique in France (1887), Archiv für Sozialwissenschaft in Germany (1888) or the new Giornale degli economisti in Italy (1886). In Spain, it would not be until 1916 that Revista Nacional de Economía was published. The presence of economic journals was linked to factors such as national economic traditions, academic institutionalisation, processes of professionalisation, etc.

In Spain, in the 1850s and 1860s, the journals of the Economist School, boasting liberalism, were the main specialised economic reviews in the country. However, unlike what happened in Western Europe, from its closure until the second decade of the $20^{\text {th }}$ century, no economic journals of national scope were published in the country. Spanish economic writers had to search for other outlets for their contributions. The financial press, aimed

1 In 1994 Italian scholars launched a research project on political economy in Italian periodicals between 1750 and 1900, producing thirty-five essays and editing three volumes: Augello (1995), Augello et al. (1996) and Bianchini (1996). Other contributions on Italian economic journals, in Augello (1994), Faucci (1996), Costa (1996) and Bini (2004). On the British case, see the works by Coats (1991, 1996), Tribe (1992), Edwards (1993). On American journals, Perlman (1991). On French, Lutfalla (1972), Albert (1990), Marco (1990, 1995, 1996), Laurent and Marco (1990), Guérin (1991), Henno (1993), Le Van-Lemesle (1996), and the collective work issued by Marco (1996). On German, Neumark (1984) and Hagemann (1991, 1996). The Spanish case has been analysed by Almenar (1996).

2 Naturally, prior to these reviews, there were already periodical publications rich in economic contents, especially during the Enlightenment, but also in the first decades of the $19^{\text {th }}$ century.

3 This gap may be just apparent, as there is neither a standard definition of specialised periodical, nor a clear distinction between economic and non-economic matter at the dawn of the discipline (Bianchini 1996, p. 4). Coats considered that the absence of specialised economic journals in Britain, from the point of view of professionalisation, was still a mystery (Coats 1996, p. 70). 
at businessmen and financiers, and daily newspapers, providing both information and opinion on contemporary economic debates, were possible alternatives ${ }^{4}$. The fortnightly or monthly literary reviews created at that time, widely ranging and aiming at the cultured elite, also provided rather an attractive opportunity. These miscellaneous reviews published works by prestigious intellectuals on a large variety of topics including political economy. Almenar stated that the vacuum of academic journals left by the Economist School periodicals was «very partially covered by literary journals of a general character» (Almenar 1996, p. 142); however, no further details on these journals have been provided. The objective of this paper is precisely to analyse the extent to which these literary reviews were substitutes for economic journals. In order to achieve this, the economic contents of a sample of four of the most important literary reviews of national scope edited in Spain in the period 1868-1914 have been checked. Analysis has shown that economic articles in these publications were not uncommon. Many renowned Spanish economic authors published their contributions in these reviews. Although they were not addressed to a specialised audience, some of these contributions provided deep insights into economic matters, beyond mere popularisation. Other economic-related contributions were also signed by non-specialised authors, with a wide variety of approaches. In all, these reviews can be said to have constituted a good replacement for the absence of specific economic journals, contributing to the process of diffusion of political economy in the nation. This article has three sections: the first describes the sample of literary reviews used for analysis. The second examines the economic contents of these reviews. The third deals with authorship of economic contributions before offering some conclusions.

\section{LITERARY REVIEWS IN THE LAST THIRD OF THE $19^{\mathrm{TH}}$ CENTURY}

At the end of the 1860s the journals of the Spanish economic liberal school, the Economist School, closed down. Following European patterns, these journals had been created as the organ of the School and its society branch the Sociedad Libre de Economía Politica to spread their ideas on economic liberalisation and free trade ${ }^{5}$. Members of the School (the economistas) were

${ }^{4}$ The contribution of the financial press and of the daily press to the diffusion of economic ideas is beyond the scope of this paper, but deserves careful attention. As an example, during the 1868 Revolution, two financial papers La hacienda española and La hacienda maintained opposing positions on the major issue of economic liberalisation, supporting them with doctrinal articles. Also in 1868-1869, the daily newspaper La Voz del Siglo, managed by Moret of the Economist School, printed contributions by economists such as Rodríguez, Echegaray or Sanromá, supporting the liberal policy of the government.

5 These reviews had a precedent, the Revista Económica de Madrid, which appeared in 1842. Almenar considered it as probably the first explicit Spanish vehicle for the spread of the ideas of a specific group of economists and philosophers linked to academia. Founded by Valle, a professor of 
the main contributors, supporting individualistic liberalism in its French radical version. In their view, political economy was not the «dismal science»; on the contrary, it embodied a powerful idea of modernity and offered a route to improving society's standards of living ${ }^{6}$. These journals had a strong pedagogical bias, seeking to persuade public opinion, but also served economistas to create a sense of community of initiates and self-consciousness as economic experts. The first of them was El economista (1856-1857), a twenty-page fortnightly journal, fiercely critical of protectionism ${ }^{7}$, doctrinally inspired by the Journal des économistes ${ }^{8}$. It was run by Gabriel Rodríguez, a prominent member of the School. Besides articles on economic matters (especially trade, taxation and public budget), it supplied information on events organised to support free trade, and published the records of the meetings of the Sociedad Libre. It also included translations of articles from the Journal des économistes and of foreign works (many of them by Bastiat and Molinari). La Tribuna de los economistas (1857-1858), managed by Enrique Pastor, a public finance specialist, replaced it ${ }^{9}$. Contents were similar to its predecessor. It published Walras' Théorie de la richesse sociale. After its closure, the Gaceta economista, a monthly review subtitled «economic-political journal», continued preaching economic liberalism. Published from May 1861 until at least 1865 , its leading figure was Alonso de Beraza, also a specialist in public finance. The editors' introduction to the first issue is exemplary: they praised Bastiat as the chief economist of the century, noted with satisfaction that economics had become accessible to everybody, and stated that (liberal) economic doctrines were essential to the prosperity of the nation ${ }^{10}$. The Gaceta edited reports on the

\section{(footnote continued)}

political economy at the University of Madrid, and his disciples Navarro and Zafra, it was the channel for the introduction of Krausist philosophy in Spain. It was influenced by French and English classicism, and particularly by the Journal des économistes (1841) and The Economist (1843) (Almenar 2000, p. 58).

${ }^{6}$ Fetter's words to characterise liberal economists in Britain may serve well to describe the posture of School membership: they felt that «market mechanism was the best guide to economic development» and accepted «the social and political changes that would follow as desirable» (Fetter 1980, p. 90).

7 Many contributions publicised the advantages of free trade, encouraging liberal policies. Its anti-protectionist belligerence was shown in the debates that the editorial team held with industrialists, livestock farmers or the agrarian periodical El Eco de la ganadería.

8 The Journal was a champion of economic liberalism, hosting works by Bastiat, Chevalier, Courcelle-Seneuil, Dunoyer, Passy, etc., all praised by economistas. Its influence on them was undeniable (Laurent and Marco 1996, p. 92).

9 La Tribuna's subtitle was «monthly review on political economy, administration, industry, trade and statistics». The editors stated that its aim was to popularise economics in Spain, particularly among the youth. La Tribuna de los economistas (1858), n. 13, 5.

${ }^{10}$ Gaceta economista, 1861, n. 1, 1-5. This propagandistic tone can be found in many other articles. In issue no. 5 it was written: «Economic doctrines are spreading, and those who using them defend the public interest are the heroes of the economic regeneration of Spain. Among them, there are those who work to popularise economic ideas in Spain». Gaceta economista, n. 5, 400 (1861). Tributes to Bastiat, can be found in many articles. 
conferences and meetings of the Sociedad Libre, the Athenaeum, the stock exchange, and other events in support of free trade. It also included doctrinal writings, mainly by economistas. In general, the journals of the Economist School were an important tool in the process of institutionalisation of political economy in these decades, despite their militant character and absence of plurality. This temperament led them to focus mainly on applied matters easy to transmit to the public rather than on theoretical contributions, a characteristic which Spanish economists in the second half of the century would inherit. Their extinction left a vacuum in economic reviews with a national scope ${ }^{11}$. When the Revista Nacional de Economía emerged in 1916, in its first issue the editors regretted the absence of journals devoted to systematic analysis of economic questions in the country, stating their aim of studying national economic matters from «objective and scientific points of view» ${ }^{12}$.

After the 1868 Revolution, in a period of quite intense intellectual activity, three «big intellectual journals of high quality and liberal spirit» were created in Spain, addressed to intellectuals and the new middle class with a certain educational level: The Revista de España (RDE), the Revista Europea (REU) and the Revista Contemporánea (RCO) ${ }^{13}$. Except for the Europea, whose life was short, the other two survived more than 25 years. In 1889, another journal of similar characteristics appeared, La España Moderna (LEM) ${ }^{14}$. These prestigious literary reviews cover the period from 1868 to 1914, roughly the time when Spain lacked specialised economic journals. They were published either fortnightly or monthly, contained between 130 and 200 pages and were cultural journals in a broad sense, with analogous structures. Each issue included some essays (four to eight, depending on epochs) of medium length (usually twenty to twenty-five pages), a literary section with short stories, pieces of poetry or a novel in instalments, and some other sections containing current information on many subjects (national and international politics, literary news, book reviews, reports on cultural societies, etc.). The REU had a different structure as it was a weekly

11 Some regional and sectorial publications continued hosting economic-related writings. A good example is the Revista Minera (1850-1941) linked to mining and iron and steel sectors. Economic contributions in this kind of review have yet to be assessed.

12 Revista Nacional de Economía, 1 (1), 1916.

13 These three reviews, together with the prestigious newspapers El Imparcial, La Nación and El Debate supplied the public with abundant orientation on philosophy, social sciences, history and culture (Ballantyne 1990, p. 332). Delgado pointed out that these three reviews were the "most outstanding" in this epoch, whereas Zavala said that they represented the new progressive intellectual spirit after the Revolution well (Zavala 1972, p. 188; Delgado 1983, p. 14). Pizarroso stated that the Contemporánea and later LEM were the most prestigious cultural reviews in this period (Pizarroso 1994, p. 287).

${ }^{14}$ The selection of these journals for analysis has been made from Ten and Celi's Catalogue of Scientific and Technical Journals Published in Spain in the $19^{\text {th }}$ century (1996) following the criterion of journals' presence in the catalogues of Spanish University libraries (a proxy for its diffusion). Further qualitative evidence has reinforced this selection, such as scholars' considerations, contributions authorship, contemporaries' references, etc. 
magazine of thirty-two to forty pages, in newspaper format, and consequently with shorter texts. Contents, however, were not dissimilar. Essays published dealt with a large range of disciplines, from pure sciences to liberal arts. Contributions on matters of sociology, pedagogy and education, health and hygiene, working-class issues and political economy appeared very frequently, pointing out the public's interest for new disciplines in social sciences that began their processes of consolidation as learned (and eventually academic) disciplines in this epoch. Articles were mostly informative and in general lacked critical apparatus, although there were exceptions. Contributions on economic topics comprised a wide variety of styles and accuracy and many of them were authored by recognised economists. Diffusion of this kind of review was, however, modest and limited to cultured elites. Nevertheless, they managed to survive for quite a long time (with the exception of the Europea), often owing to ownership and editors' commitment ${ }^{15}$.

The RDE (1868-1894) was founded in March 1868. It was published fortnightly and had 160 pages. In the first issue the editors defined it as a «scientific, literary and political» review, politically independent, with progressive spirit, and the aim of "spreading knowledge of general interest» ${ }^{16}$. Founded slightly before the liberal revolution of September 1868, and in spite of its alleged political independence, the RDE would approach the positions of the moderate liberal wing of the Revolution, the Unión Liberal. In general, it supported the policies of the 1868 provisional government, but soon showed pessimism about its capability to set up strong democratic institutions ${ }^{17}$. The RDE proved quite open, accepting contributions of different contemporary trends of thought. Its founder, chief editor and proprietor was José Luis Albareda, a liberal conservative and strong admirer of the British political system, which he pleaded should be the model for the Revolution ${ }^{18}$. After Albareda it was edited briefly by Pérez Galdós, and then Fernando León and Sánchez Guerra, who accentuated its political bias, supporting the liberal leader Gamazo. The RDE kept its structure and sections quite regular during its 27 years of existence. Each issue contained around six or seven contributions from ten to thirty pages. Long contributions were published in successive instalments (this happened in all the reviews studied here). Contrary to its counterparts, literary pieces were not very frequent. Some sections, not regularly published, completed every issue: internal

15 A comment by Olmedilla, a novelist who published in LEM, may provide an insight on diffusion: "It circulated little, because it was not aimed to a great audience» (Yeves 2012, p. 10).

16 RDE, 1, 15 March 1868, 5-6.

17 The RDE supported a monarchist regime, fearing the advent of a republic. Later it was among the first media to support the candidature of Amadeus of Savoy to the Spanish throne. See for instance, RDE, 32, 30 June 1869. See also Dendle (1970, p. 364).

18 Albareda was an MP in 1865. After the Revolution he became a councilor of Madrid and then again an MP. During the Restoration he became minister of public works (1881-1883) and of the interior (1887-1888) in liberal administrations. Later he was the governor of the Banco Hipotecario. As minister of public works he restored academic freedom in universities. 
politics, signed by Albareda himself until 1886, an international section, a bibliographical section, and occasional sections on theatre, sciences, literary news, etc. After some troubles, during which the RDE even suspended publication for 1 year (1893), it closed down at the end of 1894. Martorell has stated that «the elite of national journalism and literature» published in the RDE, and this included names such as Valera, Pardo Bazán, Azcárate, Costa, Silvela, etc (Martorell 2011, p. 67).

The REU was quite ephemeral; it started publication in March 1874 and ceased in June 1880. It was a weekly journal, which appeared on Sundays, except for its very last period, from February to June 1880, during which it was published fortnightly. It was printed in two columns and had thirty-two pages (for a short period expanded to forty). Its managers were the philosophers Eduardo de Medina and Luis Navarro ${ }^{19}$. The REU was an important element in the renewal of Spanish philosophical trends at the end of the $19^{\text {th }}$ century. It leant towards positivism and evolutionism, but also welcomed neoKantian, neo-Hegelian and Krausist papers. It had an international vocation: foreign authors signed more than half of the contributions, translated into Spanish $^{20}$. It contained between five and seven essays on diverse topics of natural sciences, liberal arts, social sciences and politics. These contributions were necessarily brief, around six or seven pages, or were published in successive instalments. Contents were completed with some relatively fixed sections: a bulletin of sciences and arts, a bulletin of scientific societies, the political chronicle and a brief bibliographical review. A differential trait of the REU with respect to its counterparts was the special attention it devoted to scientific and technological progress, giving precise information on new machines, materials, scientific discoveries, engineering developments, etc. susceptible of application to human progress and welfare. The «Bulletin of Scientific Associations» section provided information on the meetings and proceedings of different societies dedicated to scientific and technological activities.

The RCO (1875-1907) was founded in 1875 by José del Perojo y Figueras, $\mathrm{PhD}$ in Law and Philosophy in Heidelberg and the diffuser of Neo-Kantism in Spain, who was also its chief editor. His main collaborator was Manuel de la Revilla, a republican and Darwinist. Its aim, stated in the first issue, was "to merge in one publication all the manifestations of culture [...] We don't want to limit ourselves to a single speciality, a body of ideas, or a nation; we want to reproduce all contemporary movements, turning the Revista into a true echo of our epoch, in all its aspects and variety» ${ }^{21}$. The origins of the

19 Medina and Navarro sponsored the edition of the Biblioteca Filosófica, in which Spanish translations of the complete works of Plato, Aristotle and Leibniz were published for the first time.

${ }^{20}$ In its brief life this journal published 453 texts by Spanish authors (47 per cent), 275 French (28 per cent), 112 German (12 per cent), 103 British (11 per cent) and 29 from other nations (3 per cent) (Delgado 1983, p. 51). On the philosophical trends of the REU, see also Delgado (1983, pp. 65-99).

21 Revista Contemporánea, 1875, 1:1, 3-4. 
RCO reside in Perojo's attempt to buy the REU from its owners, Medina and Navarro. As they did not reach an agreement, Perojo decided to find his own review, which actually competed with the $\mathrm{REU}^{22}$. During this first period, the review diffused the ideas of Perojo and Revilla, leaning towards positivism. Perojo, educated in Germany, contributed to the spread of the ideas of Krause and other philosophers such as Hegel in Spain (Ballantyne 1990, p. 332$)^{23}$. In 1879 the RCO was sold to José de Cárdenas ${ }^{24}$, who was close to the conservative leader Cánovas del Castillo, the leading political character in the Bourbon Restoration (1874-1922). Although remaining somehow tolerant, the RCO consequently leaned towards conservatism. It was a fortnightly review, and its length ranged between 110 and 150 pages, depending on the epoch. After July 1901 it was only published monthly, maintaining, however, its usual extension. Its structure and shape were quite similar to the RDE: it had two or three literary contributions (novels in instalments and poetry), five to seven essays (sometimes more) of different lengths, and some other sections, of quite irregular publication in the first issues of the review, and relatively fix in its period of maturity: the Bibliographical Bulletin, with comments on new books; the Political Chronicle, with observations on parliamentary discussions; and the Foreign Review, containing information on political events abroad ${ }^{25}$. When Cárdenas died, in 1907, the RCO ceased publication.

Finally, LEM (1889-1914) was a publishing house founded and managed by the financier and art collector Lázaro Galdiano. It also issued the homonymous literary journal, explicitly inspired by the Revue des Deux Mondes, which exerted a crucial influence on $\mathrm{LEM}^{26}$. It was published monthly and had around 200 pages. Its standard contents were two or three pieces of literature (novels in instalments and poetry), four or five essays of

22 This episode was written in a letter by G. Cedrún addressed to the philosopher Menéndez Pelayo (Menéndez Pelayo 1999, p. I, 268).

23 Perojo translated Kant's Critique of Pure Reason and edited some works by Darwin. De la Revilla was a professor of literature at the University of Madrid and had founded the progressive newspapers El amigo del pueblo and La crítica. See Paz (1950).

24 Cárdenas graduated in law and started his professional career in the ministry of public finance. He was elected MP several times. He was director of agriculture, industry and trade and of public instruction. In 1904, he was appointed minister of agriculture and public works for a brief period. He would also become the chief editor of the newspaper El Tiempo. Cárdenas sponsored free education.

25 According to Paz, together with the RDE, it was the most important review published in Madrid at that time (Paz 1950, p. IX).

26 According to Asún it was the only Spanish review comparable to those of the continent (Asún 1979, p. 60). The Revue des Deux Mondes, founded in 1829, where authors such as Baudelaire, Merimée, Hugo and Balzac published, was the literary review par excellence in $19^{\text {th }}$ century Europe. It created a solid, heterogeneous and critical opinion among the ascendant European bourgeoisie, achieving huge moral prestige (De Broglie 1979). Its style was quickly imitated: Revue de Paris, Nouvelle Revue, etc. in France; Quarterly Review, Edinburgh Review, Contemporary Review in Britain; Nuova Antologia and Rassegna nazionale in Italy; Die Gesellschaft and Neue Deutsche Rundschen in Germany, etc. 
variable length (usually of twenty to thirty pages) and some regular sections, which usually lasted for some years and were then replaced: the economic review (1891-1892), the international chronicle (1890-1898), the «Review of reviews», commenting on articles in other journals (1898-1914), some sections on Latin America affaires, a literary chronicle (1895-1910) and sections on bibliographical notes and new publications. In comparison with the RDE there was less political content and fewer summaries of current events, these appearing in the «Review of reviews» section, the international chronicle and the Latin American sections. LEM aimed at being an independent and eclectic publication, pursuing rigour, reflection and amenity, trying to occupy the space not reached by the REU and the RCO, and supplying information and educational, critical and European-oriented contents (Yeves 2002, p. 22). A statement by the editors, published in the first issue, announced that it would publish works on history, archaeology, arts, sciences and politics, as well as novels, short stories, poetry and literary reviews ${ }^{27}$. Following the style of Revue, Galdiano struggled to differentiate his publication from the daily press with longer contributions and to achieve a balance between rigour and amenity. There was a relative pre-eminence of literary sections with respect to the rest of journals. Some of the major Spanish writers in this period published their works (Galdós, Alas, Pardo Bazán, Azorín, Zorrilla, etc.) in LEM; others who would become famous, notably Unamuno, started publishing here ${ }^{28}$. It also edited Spanish translations of Tolstoy, Dostoevsky, Balzac, Flaubert, Zola, etc. Economic contributions were quite limited; the main contemporary specialists were almost totally absent, with the occasional exceptions of some Krausist economists who, besides, often wrote on social rather than economic issues.

LEM's vicissitudes, well reported, may be a reference for the rest of our set of literary journals. Asún pointed out that both LEM review and publishing house were never profitable: they endured only thanks to the patronage of Galdiano. In its 25 years of existence it hardly reached 500 subscribers $^{29}$ : one-third of these were cultural institutions, universities, secondary schools and libraries; one-third were liberal professionals; the other third were foreigners, Europeans and Americans. A print run of 4,000 copies was done for the first issue, Galdiano undertaking extensive marketing tasks to ensure a sizeable audience. The average print run, however, was eventually of 750 copies, quite a poor record. At the end of its life, LEM had just 300 subscribers, half of them foreigners. In all Asún qualified LEM as a «vehicle for high culture, trying to fill the vacuum of a liberal social sector and to educate young generations in a European framework». "It had

\footnotetext{
27 «Prospecto», LEM, 1889, 1.

28 Unamuno referred to LEM as «the most solid monument of the Spanish culture in the last decade of the $19^{\text {th }}$ century and first decade of the 20th» (Yeves 2012, p. 9).

${ }^{29}$ In comparison, Rassegna or Nouvelle Revue had an average of 20,000-30,000.
} 
funding, objectives, quality and good contributions... It only lacked readers» (Asún 1979, pp. 250-259). Probably this can be said of the other reviews analysed here. The same fate was suffered by LEM's publishing house: conceived as a large project to fulfil the needs of the Spanish and Latin American markets, it never made a profit. Average print runs were between 500 and 1,000 copies, well above demand. Its catalogue comprised around 600 titles; <10 per cent sold out (Asún 1979, pp. 1086-1091).

\section{ECONOMIC CONTRIBUTIONS IN CULTURAL REVIEWS}

Being miscellaneous literary reviews, these journals nevertheless published a good deal of articles on economic matters. This suggests that they had certain importance both as a means for economists to diffuse their opinions on a vast range of economic topics, and as agents for the dissemination of this field of interest among the public. Economic articles in non-specialised journals were not rare in Europe. In Britain there were no learned journals specialising in economics until the end of the century. Until then, the regular channels for economic articles were the main literary periodicals: Fetter stated that the Edinburgh Review was a close substitute for specialist economic periodicals ${ }^{30}$. Other countries had economic reviews, but this did not prevent literary reviews from publishing economic contributions. In France, the aforementioned Revue des Deux Mondes hosted economic contents. In Italy, the Nuova Antologia, «a journal of science, letters and arts», was an outstanding example of a cultural journal which, keeping its miscellaneous character, supplied its readers with coverage of economic matters, becoming a «most authoritative outlets for debate» (Augello and Guidi 1996, pp. 46-47) ${ }^{31}$. In explaining this phenomenon, Bianchini reasoned that the means through which learned economic papers were transmitted depended on the confluence of two different processes, which might have different chronology: the emergence of public opinion interested in economics and the professionalisation of political economy. In Britain and France, specialised economic journals emerged relatively late because public opinion became interested in economics quite early and economic articles were already appearing in non-specialised periodicals ${ }^{32}$. There is another phenomenon related to the late professionalisation of political economy in general: the absence of standards to define the

30 Some other reviews were the Quarterly Review, Westminster Review, Contemporary Review, Fortnightly Review, etc. For instance, the Contemporary and the Fortnightly, among others, published contributions by Marshall, Jevons, Bagehot, Cairnes, etc. The Westminster edited utilitarian writings including contributions by James and John Stuart Mill. See Coats (1996, pp. 63-71).

31 This review was linked to the liberal Florentine society Società d'economia politica, but promoted pluralistic debate.

32 In other countries the professionalisation of economics developed before a critical mass of public opinion had emerged (Bianchini 1996, pp. 3-6). 
profession of the economist. Stigler pointed out that although specialisation as a full-time economist was becoming common at the end of the $19^{\text {th }}$ century in Britain and the United States «historians and political scientists could still write on economic subjects with impunity». Conversely, a good deal of writing produced by economists appeared in non-specialised journals (Stigler et al. 1995, p. 332) ${ }^{33}$.

In this regard, the analysis of the economic contributions in our sample of journals leads inescapably to the problem of selection of these "economic» articles. Authorship is a slippery criterion, the consequence of the absence of professional standards and the fact that many authors who could be qualified as economists also wrote on topics alien to this field. Thematic criteria are also intricate: as Coats pointed out, in the $19^{\text {th }}$ century "the problem of distinguishing clearly between economic and non-economic publications is daunting» (Coats 1996, p. 63). Topics that fell within the scope of interest of economists in the $19^{\text {th }}$ century were later tackled by fields such as sociology or political science. This is particularly the case of writings on social matters, labour affairs, trade unions, political articles on socialism and anarchism, female workers, etc. Economic writers in the $19^{\text {th }}$ century were also interested in new social sciences, as they might provide new tools to understand social changes: sociology, public health and hygiene, education, etc.

In our sample of reviews, besides contributions, which can reasonably be deemed economic (agriculture, banking, economic sectors, public finance, economic doctrines, economic history, etc.), contributions dealing with the working class and social issues have been also considered as economicrelated, as these topics constituted a major concern for economists in the last decades of the century (those not having any connection to economics have, naturally, been excluded $)^{34}$. Contributions on technical and engineering issues, education, health and hygiene, socialism, etc. have been discarded, except if directly linked to economic matters. Very short economic notes and merely informative bibliographic notes have also been excluded. Nevertheless, a tidy classification seems impracticable. Almost 600 articles on economic issues in the life of these four reviews have been compiled, representing over 1,200 instalments (contributions split into parts published successively). As shown in Table 1, the RDE was the most «economicoriented» review, with slightly less than one piece on economic matters per issue and 13 per cent of its contents on economic questions. The REU and the RCO had over one economic contribution every two issues and around

33 Stigler calculated that during the period 1892-1901, almost 40 per cent of the 377 economic learned articles published in the United States appeared in three non-specialised journals.

34 Economists' concern for the social issue was not uncommon. Labour and social problems represented a good deal of economic contributions in other European countries. For instance, Le Van-Lemesle explained that similar contents were delivered by the Revue d'économie politique in France (Le Van-Lemesle 1996, p. 115). 
TABLE 1

ECONOMIC CONTENTS IN MAJOR LITERARY REVIEWS IN SPAIN, 1868-1914

\begin{tabular}{|c|c|c|c|c|c|c|}
\hline Review & $\begin{array}{c}\text { Eco } \\
\text { articles }\end{array}$ & $\begin{array}{c}\text { Eco } \\
\text { instalments }\end{array}$ & $\begin{array}{c}\text { Total } \\
\text { issues }\end{array}$ & $\begin{array}{c}\text { Eco inst. } \\
\text { per issue }\end{array}$ & $\begin{array}{c}\text { Av. essays } \\
\text { per issue }\end{array}$ & $\begin{array}{c}\% \text { Eco } \\
\text { contents }\end{array}$ \\
\hline $\begin{array}{c}\text { RDE } \\
1868- \\
1894\end{array}$ & 242 & 519 & 596 & 0.87 & 6.5 & 13.40 \\
\hline $\begin{array}{c}\text { REU } \\
1874- \\
1880\end{array}$ & 104 & 200 & 319 & 0.63 & 6.5 & 9.65 \\
\hline $\begin{array}{c}\text { RCO } \\
1875- \\
1907\end{array}$ & 189 & 427 & 686 & 0.62 & 7 & 8.89 \\
\hline $\begin{array}{c}\text { LEM } \\
1889- \\
1914\end{array}$ & 64 & 83 & 312 & 0.27 & 4 & 6.65 \\
\hline Total & 599 & 1229 & & & & \\
\hline
\end{tabular}

Note: RDE: Revista de España; RCO: Revista Contemporánea; REU: Revista Europea; LEM: La España Moderna.

Source: Calculated from RDE, RCO, REU, LEM, Ballantyne (1990), Paz (1950) and Yeves (2002).

9 per cent of their contents on this area. LEM was the least economic with just one contribution every four issues, 6.6 per cent of its contents.

It can therefore be said that economic articles in Spanish literary reviews in this epoch were far from rare. Publishing in these reviews was probably appreciated by economic writers, as they were valued reviews of national scope in which major names of the intellectual elite published. Quality and length of writings are diverse, ranging from near-scholarly contributions to short observations on any economic topic authored by non-specialists. Articles were seldom theoretical; they had mainly an applied or descriptive orientation. Complex reasoning is rare, the level of analysis of economic questions being normally not very detailed and of popularising tone, corresponding to the audience of these journals. These economic contributions were not uniformly distributed. An intense temporary collaboration by an author, the outbreak of a particular debate, or the publication of a very long text in many successive instalments could increase the economic contents of a journal provisionally. ${ }^{35}$

35 For instance, it seems that the arrival of Cos-Gayón - an expert in finance - to the board of editors of the RDE at the end of 1868 fostered the publication of economic articles. Also when Galdós left the editorial board of the RDE in 1873, the number of economic and political articles 
TABLE 2

ECONOMIC TOPICS IN SPANISH LITERARY REVIEWS, 1868-1914

\begin{tabular}{|l|c|c|c|r|}
\hline Topic & Total Arts. & $\%$ & Total Inst. & $\%$ \\
\hline Agriculture & 84 & 14.02 & 192 & 15.62 \\
\hline Bank, finance, money & 29 & 4.84 & 43 & 3.50 \\
\hline Economic Doctrines & 47 & 7.85 & 113 & 9.19 \\
\hline Economic History & 33 & 5.51 & 71 & 5.78 \\
\hline Economic Sectors & 56 & 9.35 & 71 & 5.78 \\
\hline Population & 29 & 4.84 & 50 & 4.07 \\
\hline Public Finance & 105 & 17.53 & 209 & 17.01 \\
\hline Social Issues & 57 & 9.52 & 107 & 8.71 \\
\hline Statistical studies & 14 & 2.34 & 78 & 6.35 \\
\hline Trade & 37 & 6.18 & 45 & 3.66 \\
\hline Working class issues & 56 & 9.35 & 145 & 11.80 \\
\hline Other topics & 52 & 8.68 & 105 & 8.54 \\
\hline Total & 599 & 100.00 & 1229 & 100.00 \\
\hline
\end{tabular}

Note: RDE: Revista de España; RCO: Revista Contemporánea; REU: Revista Europea; LEM: La España Moderna.

Source: Calculated from RDE, RCO, REU, LEM.

Table 2 shows a thematic classification of economic contributions. The most common topic was public finance, adding up to around 17 per cent of all articles and instalments. This cannot surprise, as public finance was among the most controversial economic issues in the second half of the century. Two issues accounted for the majority of these contributions: the first was custom duties, linked to the debate on trade policy (free trade vs. protectionism) in vogue since the mid decades of the century. The effects of trade liberalisation policies after 1869 , successive agreements with other

(footnote continued)

decreased considerably in order to lower the political profile of the review Ballantyne (1990, p. 336). During the ten following years economic contents decreased, but in the second half of the 1880s, and until its closure, the RDE again published many articles on economic topics, mainly on social issues. In the RCO Gil Maestre published articles on workers' matters in 63 instalments between 1898 and 1900. The same happened in LEM with authors such as Fuentes and García Alix in the second half of the first decade of the $20^{\text {th }}$ century. 
nations and Spain's protectionist turn were all profusely addressed. The second was the problem of the public budget and tax reform. Articles on public debt, state monopolies or particular taxes completed public finance articles. In comparison with other economic topics, it is regarding public finance that there was a relative abundance of writings authored by renowned economists: academicians such as Rodríguez, but above all, finance ministers and public officials connected to economic administration such as Pastor, Ruiz Gómez, García Barzanallana, Villaverde, or García Alix. Agriculture represented the second most common topic (around 15 per cent of contributions), which cannot surprise in a country with an agrarianbased economic structure. The problems of agrarian underdevelopment, land property, productivity and the agrarian crisis of the 1880 s were addressed $^{36}$.

As the century approached its end, reviews allowed increasing space to the social problem (cuestión social): working-class welfare, work conditions, labour associations, women and children's work, wages, labour accidents, social insurances, education, hygiene and sanitary conditions in popular classes, etc. Articles on the role of women in the labour market emerged strongly, as well as on the spread of socialist and anarchist ideas. Articles related purely to labour-specific matters amounted to 10 per cent of economic contributions. Adding up articles on the "social issue» in general, the figure reaches 20 per cent ${ }^{37}$. Major economists paid attention to this matter, but with the exceptions of Azcárate, Sanromá and Posada, it was quite sporadic, leaving these issues to other writers, who adopted a variety of approaches. Some economists, however, especially Krausists, devoted many of their contributions in these journals to matters such as education, health or workers' sociological studies, not included in our sample of economic articles.

Economic doctrines accounted for 8-9 per cent of contributions. Some of these articles discussed the ideas of economists or schools of thought: Azcárate on the ideas by Cairnes (REU 1875), Pires de Lima on Marx's doctrines (RCO 1899), Estasén on Bagehot (RCO 1877), Sanromá on Carreras (RDE 1881 and 1885), Castelar on Turgot (RDE 1888), Carreras on Chair Socialism (RDE 1883), etc. Other contributions dealt with economic categories and methods: Feu on the value theory and the fundamentals of

36 The most active authors regarding the agrarian crisis were the economist Sánchez de Toca (a series of papers in the RCO in 1887), and the scientist Becerro de Bengoa (another series in the RDE in 1888).

37 If articles on education, hygiene and other social concerns are added, this set of matters would become the star topic for Spanish intellectuals at the end of the century. There were some intense periods in this regard: for instance, LEM edited around 15 essays on education in 1899 , almost a third of the total number of articles that year (many were translations of foreign works). The REU published three consecutive series of articles on particular social matters amounting to forty instalments: Olías (on the history of the labour movement, 1875), Sanromá (work conditions, 1876) and Olmedilla and Puig (hygiene, 1877). 
economic science (RDE 1871), some unsigned contributions in the REU on value, wealth, distribution and credit (1878), Rodríguez on the concept of political economy (RDE 1885), Carreras on doctrines on economics and statistics (RCO 1885), García de Otazo on wealth distribution (RCO 1896), Estasén on value theory (RDE 1879), Escudero on natural economic laws, exchange, price and wealth, etc. (REU 1879). Exceptionally, the REU published Piernas Hurtado's booklet Vocabulario de la economía (1877). Translations of texts by well-known foreign economists on this topic were abundant in the REU: Laveleye on new trends in political economy (1875), MacLeod on the concept of political economy (1875), Jevons on international currency (1876) or Geroult on Saint Simon (1879). There is just one article dealing with the new methodologies in political economy, by González de la Calle (RCO 1903) on Menger's work, comparing it with the classical school and historicism. There were hardly any other mentions of marginalism.

Other economic contributions were reports on particular economic sectors, economic conjuncture or specific issues. Industrial and transport sectors represented 9 per cent of articles, but only 6 per cent of instalments (articles were usually brief descriptions). Writings on trade represented 6 and 4 per cent, respectively. Two other topics aroused interest, population and economic statistics, amounting to around 7 per cent of articles and 10 per cent of instalments (some of them were quite long, especially those describing the economy and population of regions or countries) ${ }^{38}$. Papers on economic history were not rare (slightly more than 5 per cent of contributions $)^{39}$. Money and banking matters were also addressed, for instance the problem of the metallic standard, which raised some debate at the end of the $1880 \mathrm{~s}^{40}$. On some occasions, these reviews hosted debates on controversial matters. One of the most important was the discussion between free trade and protectionism, a central topic in the journals of the Economist School, which continued through the Restoration. Economistas continued defending free trade in these literary reviews (even if less enthusiastically): there were contributions by Pastor (RDE 1869), Ruiz Gómez (two in the RDE 1879), Carreras (RDE 1881 and 1882), and above all, Rodríguez, who, besides other contributions on international trade (RDE 1872, 1880 and 1881), upheld the defence of free trade at the moment of the protectionist turn in Spain in the RDE against Cánovas ${ }^{41}$.

38 Here the figure of a member of the Economist School stood out: Jimeno Agius, among the most prolific economic writers in our reviews, who published a total of twenty-seven articles in sixty-eight instalments.

39 However, half of them were authored by Francisco Cárdenas in the RDE between 1871 and 1875, on the economy in the Middle Ages.

40 Sánchez de Toca wrote four articles on this topic in the RCO in 1893-1894.

41 Rodríguez wrote on the protectionist reaction in Spain in LEM (1888, 1891, 1894 and 1895) and Cánovas published his famous text How I turned doctrinally protectionist in the RDE in 1891. Several other authors wrote on this topic too. On the customs issue the papers by Gisbert (REU 1875), Estasén (RCO 1879), Pedregal (RDE 1880) and Barzanallana (RCO 1881) stood out. 
TABLE 3

SPECIALISATION IN ECONOMIC TOPICS OF LITERARY REVIEWS, 1868-1914

\begin{tabular}{|c|c|c|c|c|c|c|c|c|}
\hline \multirow[b]{2}{*}{ Topic } & \multicolumn{2}{|c|}{ RDE } & \multicolumn{2}{|c|}{ REU } & \multicolumn{2}{|c|}{ RCO } & \multicolumn{2}{|c|}{ LEM } \\
\hline & Inst. & $\%$ & Inst. & $\%$ & Inst. & $\%$ & Inst. & $\%$ \\
\hline Agriculture & 67 & 12.9 & 39 & 19.5 & 76 & 17.8 & 10 & 12.0 \\
\hline $\begin{array}{l}\text { Bank, finance, } \\
\text { money }\end{array}$ & 13 & 2.5 & 4 & 2.0 & 19 & 4.4 & 7 & 8.4 \\
\hline $\begin{array}{l}\text { Economic } \\
\text { Doctrines }\end{array}$ & 27 & 5.2 & 50 & 25.0 & 32 & 7.5 & 4 & 4.8 \\
\hline $\begin{array}{c}\text { Economic } \\
\text { History }\end{array}$ & 56 & 10.8 & 6 & 3.0 & 3 & 0.7 & 6 & 7.2 \\
\hline $\begin{array}{l}\text { Economic } \\
\text { Sectors }\end{array}$ & 24 & 4.6 & 17 & 8.5 & 26 & 6.1 & 4 & 4.8 \\
\hline Population & 26 & 5.0 & 4 & 2.0 & 18 & 4.2 & 2 & 2.4 \\
\hline Public Finance & 109 & 21.0 & 16 & 8.0 & 73 & 17.1 & 11 & 13.3 \\
\hline Social Issues & 63 & 12.1 & 6 & 3.0 & 23 & 5.4 & 15 & 18.1 \\
\hline $\begin{array}{c}\text { Statistical } \\
\text { studies }\end{array}$ & 59 & 11.4 & 4 & 2.0 & 14 & 3.3 & 1 & 1.2 \\
\hline Trade & 22 & 4.2 & 4 & 2.0 & 14 & 3.3 & 5 & 6.0 \\
\hline $\begin{array}{l}\text { Working class } \\
\text { issues }\end{array}$ & 24 & 4.6 & 31 & 15.5 & 85 & 19.9 & 5 & 6.0 \\
\hline Other topics & 29 & 5.6 & 19 & 9.5 & 44 & 10.3 & 13 & 15.7 \\
\hline Total & 519 & 100.00 & 200 & 100.00 & 427 & 100.00 & 83 & 100.00 \\
\hline
\end{tabular}

Note: RDE: Revista de España; RCO: Revista Contemporánea; REU: Revista Europea; LEM: La España Moderna.

Source: Calculated from RDE, RCO, REU, LEM.

There was a certain degree of specialisation in some of these reviews, linked to the style of each journal, contributors' profile and period of publication. As Table 3 shows, LEM leant relatively more to social concerns, especially in the 1890s, the consequence of starting publication later and its more literary orientation. The RCO paid particular attention to the problems of the working class (the long series of works by Gil Maestre), agriculture (especially debating on the agrarian crisis of the 1880s) and public finance (budget). It is interesting how the REU differentiated by devoting attention to 
economic doctrines, the outcome of its philosophical profile, and also to working-class matters ${ }^{42}$. Finally, the RDE specialised relatively in public finance, particularly at the end of the 1870 s and in the early 1880 s, with topics connected mainly to tariffs.

Economic essays were just a part - albeit the main one - of the economic contents of these reviews. Sections on news and politics, national and international, provided economic information usually on current matters and discussions in Spain and abroad. In the RDE, leaving aside the shortlived «Economic Review»(1891-1892), economic information and opinion were fairly frequent in the international section, the Latin-America section and the «Review of Reviews». The RCO also had an economic section for some years in which ongoing problems were discussed. The book review section in all these journals also supplied fairly regular information and comments on new economic books published in Spain and abroad. Often it was just a brief note on a new book, but occasionally there were long reviews of economic texts, including enthusiastic invitations to the audience to read them. This no doubt contributed to the spread of political economy into cultured Spanish society. Virtually all major economic books edited in Spain at that time were reviewed in our journals (works by Piernas Hurtado, Olózaga, Carreras, Navarro Reverter, Sánchez de Toca, Sanz Escartín, etc.), and a relevant sample of foreign volumes too ${ }^{43}$. A further mention, albeit at a different level, should be made for LEM's publishing house, which contributed crucially to the promotion of political economy in Spain and the arrival of new ideas through the edition of a good number of translations of foreign economic books. These editions included Tratado de economía política by Marshall (1911), Economía política y geométrica by Fisher (1912), Teoría sobre los cambios extranjeros by Goschen (1894), Economía, a collection of texts by Von Neumann, Wagner and other Chair Socialists (1894 and 1913), Economía política by Laveleye (1895 and 1909), Economía politica by Leroy Beaulieu (1900), Protección y librecambio by George (1901), Campos, fábricas y talleres by Kropotkin (1900), Las crisis industriales en Inglaterra by Tugan-Baranovski (1914), etc. It also published Mill's memories $(1892)^{44}$.

42 The latter was the outcome of two long series of articles on the working class by J.M. Olías and J.M. Sanromá. Its relative specialisation in agriculture was the outcome of a long transcription of a conference of J. Vilanova in the Athenaeum of Madrid in seventeen parts.

43 The foreign works reviewed included authors such as Marx (El capital, RCO, 1887; Salaires, prix, profits, RCO 1899), Mill (La esclavitud femenina, RCO 1891), Puynode (Estudios sobre los principales economistas, RDE 1868), Wolowski (Le change et la circulation, RDE 1869), Schmoller (Política social y economía política, RCO 1905), Gide (Tratado de Economía política, LEM 1896), Thornton (On labour, RDE 1869), Laveleye (De la propriété, RCO 1891, Essais et études RCO 1894), Worms (La science et l'art en Economie Politique, RCO 1896 and RDE 1897), Cossa, (Histoire des doctrines economiques, LEM 1899), Bastable (La théorie du commerce international, LEM 1900), etc. Works by marginalist authors or by early neoclassical authors (notably Marshall) are nevertheless absent. 


\section{AUTHORSHIP: ACADEMICIANS, PUBLIC OFFICIALS, PROFESSIONALS AND LAYMEN}

Authorship of these economic contributions constituted a mixture of well-known academic economists, public officials and policymakers connected to economic administration, professionals, businessmen, journalists and intellectuals with no apparent proficiency in economic matters. The degree of expertise with which economic matters were dealt was consequently varied, ranging from specialised insight to laymen's approaches, the outcome of the absence of professional economic standards and the blurred boundaries of the domain of political economy. University teachers of political economy and public finances, who could in general be considered figures close to professional economists (and, consequently, prone to produce articles on economic affairs), did not prove very prolific in literary reviews ${ }^{45}$. University professors of the Economist School, while limiting their writings on political economy, expanded their fields of interest to other matters. The exception was Rodríguez, the professor of political economy and administrative law at the School of Civil Engineers in Madrid, who published eleven contributions mainly on international trade (in support of free trade), ten of them in the RDE (1872-1894) and one in LEM (1895) ${ }^{46}$. Less prolific was Carreras, a professor of political economy at the Institutes of Saragossa and Madrid, who published six contributions on economic doctrines (RCO 1879, 1885; RDE 1881, 1883) and international trade (RDE 1881, 1882). Sanromá, who held the chair in political economy in Santiago, published eight articles, five on the working class (REU 1876), one on the monetary conference of 1881 (RCO 1881), a long review of Carreras' Philosophie de la science économique (RCO 1881) and his necrology (RDE $1885)^{47}$. Figuerola, teaching economics in Barcelona and Madrid, published only one contribution, on trade (RDE 1880), and Salvá another on women and economics (RDE 1872). Other economic professors of the School (some of the most renowned) did contribute to these reviews, but on topics alien to economics. An extreme case was Echegaray, who wrote ten articles on

44 LEM's catalogue had 609 titles, of which around twenty were on economics. Besides the book mentioned, other authors translated were Caillaux, Loria, Stourm, Boccardo, Ingram, Rogers, Antoine, etc. There were also many works on sociology by Spencer, some of them with economic references, and the Antidühring by Engels (Yeves 2002, p. 26).

45 Many authors have pointed out that the process of professionalisation of political economy is closely connected to the consolidation of university chairs in this discipline. See for instance, Barucci (1988, p. 28) and Hagemann (2001, p. 152). However, this is a controversial matter, for there might be a distinction between academic economic professionalisation and economic professionalisation in general, which embraces a larger group of theoretical and practical «experts» in political economy, heterogeneous and difficult to study (Augello 1992, pp. 10-13).

46 In these articles Rodríguez attacked Cánovas, who having followed free trade ideas, became a convinced protectionist. See Sánchez and Malo (2001, p. xxvi). Rodríguez had an interesting further contribution on the concept of political economy (RDE 1885).

47 Sanromá edited his memories in twenty-two instalments in the RCO from 1886. 
mathematics, physics, literature and philosophy in LEM and the RDE, and even published his Recuerdos in no fewer than 120 instalments in LEM between 1894 and 1911, but nothing on economics. The same is true of Moret, who published articles on the politics of Spanish colonies, law, education, etc. in LEM and the $\mathrm{RDE}^{48}$. Other academic economistas devoted their attention to a variety of non-economic topics ${ }^{49}$. This diversification of interests was not a particular feature of Spanish economic writers, though. As Coats showed, Jevons, Bagehot and other English economists dealt with other topics too, showing versatility and proving that they were «men of letters» rather than mere political economists (Coats 1996, p. 66).

Relative disregard for economic topics was not only the case of economistas. Contributions by Krausist economic professors are also noticeable on account of their scarcity. Azcárate, who taught at the University of Madrid, wrote quite regularly in the RDE, the RCO and LEM, but seldom on economics. He published five economic-related essays, all of them on the social issue (REU 1875; RDE 1878, 1892, 1894), and one on the British economist Cairnes (REU 1875). The rest of his contributions, over twenty, dealt with philosophy, law, morals and politics ${ }^{50}$. Piernas Hurtado, a professor of political economy and public finances in Oviedo, Saragossa and Madrid, was almost totally absent from these reviews, except for the publication of his Vocabulario de economía (REU, 1879) and a review of the book La cuestion económica by Sanz Escartín (LEM 1890), and he did not make any specific contribution $^{51}$. Buylla, teaching economics in Oviedo, made only six contributions, all of them book reviews (especially economic) in LEM. González Posada, another Krausist professor (not teaching economics, though), also followed this trend but delivered nine economic contributions too, most of them on the social issue in LEM $^{52}$. Krausist economists' most significant contributions in these journals were on sociology, politics, education, philosophy, social matters, hygiene, etc. Posada published 27 essays, most of them in LEM, where he also delivered dozens of book reviews on sociology,

48 Echegaray was a professor of economics at the School of Civil Engineers. Moret had a chair in political economy and public finance in Madrid, but his life was closely linked to politics. He was a member of parliament in uncountable legislatures, minister several times and prime minister in 1905. He also had interests in many businesses.

49 These topics included education (Colmeiro, RDE 1869; Sanromá, RDE 1884), gender issues (Salvá, REU 1875), slavery (Sanromá, RDE 1881), law (Rodríguez, RDE 1890; Salvá, two in REU 1878), socialism (Carreras, RDE 1883), philosophy (Rodríguez, RCO 1876), and even prisons (Carreras, RDE 1883), ancient history (Figuerola, RCO 1883) and music (Rodríguez, REU 1877). Many of these professors developed other activities in business and politics. See Román (2003, pp. 43-82).

50 They were published in the RDE 1876-1884 and 1890-1891 (16), the REU 1876-1877 (5) and the RCO 1876 (1).

51 The RDE published also a talk given by him in the society El Fomento de las Artes (1892).

52 Posada also contributed with an economic analysis of ancient societies, trade and two articles on the city of Buenos Aires, with much economic information (RDE 1891; LEM 1904-1912). He wrote many reviews of economic books for LEM. 
politics, philosophy and education. Alas, a professor of political economy in Saragossa, did not write a single text on economics, preferring social matters, education and literature. Krausists' preferences for these topics cannot surprise, given their concern for new social sciences other than economics. Their presence in these journals was high, especially in LEM and the RDE (it was meagre in the RCO), especially in the 1860s and 1870s, when these journals hosted a lively controversy between Krausist philosophers and Catholic-conservative intellectuals ${ }^{53}$. Apart from economic professors linked to the Economist School and Krausism, there were hardly any more contributions by academicians. Only Duran y Bas, a professor of mercantile law, made two on social matters (RCO 1897-1899) ${ }^{54}$.

Public officials and policymakers connected to economic administrative positions formed a large group of authors. Former and future ministers of finance were extremely prolific. Among the most productive, Ruiz Gómez, close to the economistas, made eight contributions on budget matters, trade, and the French economy and colonies, all but one in the RDE ${ }^{55}$. Cos-Gayón, minister of finance three times between 1880 and 1891, collaborated with the RDE, where he published seven articles on money, trade, agriculture and economic history. He also used to write the section of literary news and sometimes the political section ${ }^{56}$. García Barzanallana published ten articles, all of them on public finance in the REU (1878-1879) and the RCO (18811885). The list is completed with the contributions by García Alix (four on banking, trade and public finances in LEM in 1907 and one more in the RDE on international trade in 1887), Navarro Reverter (three on labour, industry and general economic matters in the RCO 1889 and the RDE 1884, 1891), Pelayo Cuesta (three papers on public finance in 1869-1874 in the REU and the RDE), Pedregal (three articles on customs and international trade, agriculture in Ireland and the budget in the RCO 1879; RDE 1880 and 1881); Pastor (two on public finance in the RDE in 1868-1869), Delgado (two on public finance and agriculture in the RCO 1894-1895), Salvador (one on the marquis of Ensenada) and Villaverde (one contribution, the transcription of a conference he gave in the Athenaeum on taxation $)^{57}$. Other authors linked

53 Prominent Krausists published their contributions in all these journals, but their critics' texts were edited mainly in the RCO. At the time it was managed by Perojo, the RCO launched a strong attack against Krausism in the articles written by Revilla. The RDE also published a long critical revision of Krausism by Caminero in 1869-1870.

54 Other economics professors, some of them the authors of celebrated works on political economy or public finance, were absent in our reviews: Olózaga, Carballo, Madrazo, Miranda y Eguía, etc.

55 RDE 1878-1882 and RCO 1882. Ruiz Gómez was appointed general director of public monopolies with Figuerola as finance minister in 1868. He would become minister of finance in 1871-1872.

56 Cos Gayón taught history of political law and public finances in the Athenaeum of Madrid.

57 Pastor had been minister of finance in 1853, Barzanallana in 1876-1877, Pelayo Cuesta in 1883, Salvador in 1894 and 1905-1906, Navarro Reverter in 1895-1897, 1906-1907 and 1912, Villaverde in 1899-1900 and 1902-1903, Delgado in 1906 and Pedregal, very briefly, in 1921. 
to public economic departments also stood out: the most prolific were Jimeno Agius, of the Economist School, who published twenty-six articles in sixty-four instalments on statistics mainly in the RDE but also in the REU and the RCO, and Sánchez de Toca with twelve contributions divided into two groups of topics: the agrarian crisis in the decade of 1880 and money issues in the $1890 \mathrm{~s}^{58}$. Modesto Fernández, a public official at the ministry of finance, made four contributions to the REU on public finance, economic history and the industrial crisis (1874-1878). Other renowned politicians less directly connected to economic positions also made economic contributions: Cánovas, the main figure in the Restoration, wrote three, including his famous statement on protectionism (RDE 1891). Castelar, a former prime minister, collaborated prolifically with LEM, where he wrote the «International Chronicle» section from 1890 to 1898. He also wrote a paper on L. Say's text on Turgot. Less known albeit very prolific contributors were F. Cárdenas, minister of justice in the first Cánovas cabinet, who published 17 articles in 40 instalments in the RDE between 1868 and 1875, or Gil Maestre, a politician who published eight essays in sixty-three instalments on labour matters in the RCO (1898-1900).

Other contributions were made by professionals, scientists, intellectuals and businessmen. This was the case for instance of the engineers Alzola, who wrote four economic essays in the RCO (1893-1901) besides many more mostly on education, Álvarez Sereix, who published six economic contributions in the RCO (of which he was the editor) between 1885 and 1895 and Jordana y Morera (the author of seven papers, most of them on forest economics); and the physicists Becerro de Bengoa (five contributions on agriculture and industry in the RCO and the RDE in 1881-1892) and G. Vicuña (five articles on industry in the REU in 1874-1875). P. Estasén, an intellectual sponsoring protectionism, the diffuser of List and Bagehot's ideas in Spain, made four contributions in the RCO and the RDE in 1877-1879, taking part actively in the debate on free trade and protectionism. Labra, a journalist, the leader of the Spanish anti-slave league, published six articles in the RDE in 1890-1891 on labour and the social issue. Polo de Bernabé, an entrepreneur, made three contributions on public finance in the RDE between 1868 and 1874. The list of authors in these literary reviews is completed with other writers with no apparent expertise in economic issues, but who nevertheless made economic contributions, usually descriptive. Finally, there were some translations of foreign economists' texts, especially in the REU, which in its short life published papers by Jevons, J. S. Mill, Laveleye, Macleod, Chevalier or Wolowsky. LEM published a part of Mill's memories and an article by Nogaro. The RCO edited

58 José Gimeno Agius, a lawyer, was appointed general governor of the public finances of Philippines in 1870, and in 1883 the chief of the public finances inspection. Sánchez de Toca was the mayor of Madrid in 1896 and minister of agriculture and trade in 1900. 
a paper by Mill $^{59}$. Translations of foreign authors dealing with social matters appeared more frequently.

Analysis of authorship in Spanish literary journals seems to point out that economic contributors in the last third of the century were connected more to politics than to academia. This fits the kind of economic contributions made, mainly applied or descriptive, not leaning towards theoretical developments, and reflecting a diversity of interests, even beyond political economy. Inhibition of academic economists in this period contrasts with the activity of the Economist School in the previous decades. It seems that the gap left by the progressive withdrawal of the economistas was not filled by new generations of academic economists, but by economic experts linked to public administration, politics and, to a lesser extent, business, writing on applied issues, especially topics such as the management of public finance and economic policy. Krausist economists were perhaps the group called to succeed the economistas, but unity and commitment to political economy cannot be compared, and their intellectual interests went beyond political economy, extending to other social sciences.

This leads to the question of why were there no economic journals in Spain in this epoch. The Krausists' diversity of interests possibly made them think that a journal specialising in political economy was too narrow a framework for their ideas. Lack of doctrinal controversy might also have played a role: the Krausists never proposed alternatives to economic liberalism (they simply demanded a more active role of government, mainly on social issues), and there was hardly a Spanish version of the methodological debate. This deprived Spanish economists of incentives to create organs to strengthen doctrinal positions (this was crucial in other countries, such as Italy). In all, demand for economic journals was probably too small and partially satisfied with foreign reviews, especially Journal des Economistes ${ }^{60}$. This might be connected to a delay in the two processes pointed out by Bianchini, notably the second: the existence of public opinion interested in political economy in Spain is defensible, but perhaps was not large enough so that specialised reviews could emerge. In any case this debate remains open: Coats said that the emergence of economic journals is determined by a combination of supply and demand factors, such as the growth of knowledge in that field, the availability of a certain number of competent authors and the existence of

59 Articles translated in the REU were by Jevons (La moneda internacional, 1876), J. S. Mill (Memorias, 1874), Laveleye (Nuevas tendencias de la economía política y el socialismo and La propiedad territorial, 1875), Macleod (¿Qué es la economía política?, 1875), Chevalier (De los medios de un estado para regenerar su Hacienda, 1875) and Wolowsky (El encarecimiento de los medios de subsistencia, 1875). LEM published Nogaro's El problema del cambio español (1911). RCO edited Mill's El socialismo (1879).

60 Almenar highlighted the fact that many economics professors had a poor background and loose commitment to economics as reasons for the lack of economic journals. Besides, the debate of free trade and protectionism slowly ended with the latter position progressively gaining support after 1874. In all, there was insufficient critical mass. See Almenar (1996, pp. 141-142). 
enough audience. However, sometimes the occurrence of these forces does not produce the expected outcome, as the British case shows. Although preconditions for economic periodicals to emerge existed much earlier, British economists placed their contributions in non-specialist organs until the end of the century (Coats 1991, p. 182). Differences in processes of institutionalisation and professionalisation of political economy in this period in different nations are linked to the existence and style of economic journals. In the British case, Coats stated that late academisation of political economy could explain the absence of economic journals ${ }^{61}$. Professionalisation through academia might also account for the theoretical bias of British economics. In France, there was a connection between economics and politics, but universities also mattered ${ }^{62}$. In Germany there was also a linkage of journals to academic professionalisation (Hagemann 1996, pp. 83-86) ${ }^{63}$. In the Italian case, economic journals expanded with political and administrative unification, together with the institutionalisation and professionalisation of political economy in universities and the development of divergent schools ${ }^{64}$. The case of Spain seems to confirm Almenar's view of the Spanish model of the professionalisation of economics, whose main feature would be a strong relationship with the professionalisation of politics rather than with academia ${ }^{65}$. In this framework, it is not unlikely that these new generations of economists, linked to politics and fond of social matters, did not feel the need to enter the tight boundaries of economic specialised journals.

The style of economic contributions in Spanish literary journals also fits well with the literature's traditional qualification of Spanish political economy in the second half of the century: Spanish economists would have focused on applied matters, leaving aside theoretical considerations and keeping eclectic positions ${ }^{66}$. The absence of theoretical developments in Spanish economists has been considered a sign of economic intellectual poverty ${ }^{67}$.

61 Coats pointed out that academisation is not the only ground for professionalisation, but its absence can be an impediment to the availability of intellectual resources such as journals (Coats 1996, p. 69).

${ }^{62}$ For instance, it was the initiative of university law professors to create a new review to foster new economic methodology, the Revue d'Economie Politique (1887) (Le Van-Lemesle 1996, pp. 112-116).

${ }^{63}$ The pre-eminence of historicism naturally marked the contents of the reviews in which economic theory was neglected.

${ }^{64}$ In any case, political economy continued to be diffused through non-professional channels (including literary reviews; Augello and Guidi 1996, pp. 39-40).

65 Economic specialisation would have developed in the framework of the political and parliamentary system at the beginning of the $20^{\text {th }}$ century. This resulted in the absence of academic economists in parliament. See Almenar (2005, pp. 75-102).

66 Literature has particularly underlined the fact that Spain remained apart from the main economic debates in the continent, especially the spread of marginalism and the Methodenstreit. See for instance, Estapé (1990), Serrano (2001) and Comín (2001).

67 Almenar pointed out that awareness of new theoretical advances among Spanish academic economists was precluded by their lack of mathematical knowledge, the dependence on French and 
Perhaps this assertion should be globally reconsidered, in the framework of a perspective of the processes of national construction of economic traditions and economic professionalisation. In Spain, professionalisation of economics came mainly not from the academic environment, but was linked to the civil service and policymakers' action. In this framework, it cannot surprise that Spanish economic practitioners devoted more attention to applied practical problems than to theoretical developments. From this point of view, the "low quality» of Spanish economics in the $19^{\text {th }}$ century should be put into perspective ${ }^{68}$.

\section{CONCLUDING REMARKS}

Henderson (1996), Costa (1996) and Albert (1996) believe that the absence of economic journals is a factor which prevents, or at least retards, the diffusion of political economy and the production of genuine economic contributions in a country. This might well also be the case of Spain: Olascoaga, a contemporary economist, regretted in 1896 the absence of journals exclusively devoted to political economy, which, in his opinion, reinforced Spanish economists' isolation from the European scientific environment (Olascoaga 1896). But this had not always been the case: the middle decades of the $19^{\text {th }}$ century witnessed the expansion of economic journals in Spain, sponsored by the Economist School. The organs for the diffusion of economic liberalism, they followed a European trend of the creation of highly ideologised economic journals. They were, however, short-lived.

In the last third of the 19th century and the first two decades of the $20^{\text {th }}$ century, Spain lacked specialised economic journals. This and other difficulties, such as the absence of economic associations (Almenar and Llombart 2001, pp. 120-122), did not prevent political economy from continuing its diffusion. Economists sought alternative media to place their contributions. Prestigious literary reviews of national scope, addressing a learned audience, became an alternative. These reviews published contributions on political economy with some frequency. Their contents dealt mainly with applied matters, especially public finances, but there was also increasing attention towards the social problem and labour matters. The authors were reputed economists, but also professionals, journalists and other intellectuals. The absence of academic economists and a relative over-presence of economic «experts» linked to the public function were remarkable. All this reflects the particular way in which economics in Spain spread and

\footnotetext{
(footnote continued)

Italian translations of works in other languages and part-time dedication to academia (Almenar 2000, pp. 81-82).

68 As Lluch and Cardoso pointed out, there might be diverse adaptive processes in the diffusion of economic ideas at a national level (Cardoso and Lluch 1999, p. 477).
} 
professionalised: with the decay of the Economist School, the institutionalisation of political economy was moving away from academia and approaching politics, led by economic "experts» in the public administration. This also explains why, unlike other countries in which the academic professionalisation of economics was more intense, theoretical economic contributions were scarce. In fact, the literature has traditionally dismissed this «applied bias» of Spanish political economy in this period. Perhaps this view should be revisited, by considering it the result of a particular process of institutionalisation of political economy, answering precise needs and concerns.

The absence of economic journals in Spain during this long period is still to be further assessed. Factors such as a particular way of diffusion of economics, the indifference of academic economists, the diversification of interests by new generations, etc. played their role. Specialised demand for economic readings was met partially by some foreign reviews. However, in a broader framework, this demand for economic contents was met by literary journals. They kept the public informed about ongoing economic affairs, discussions on public finance, workers' demands, social matters and so on. They also gave some hints of new theoretical and methodological approaches. Literary journals played an important role in the diffusion of political economy among Spanish-cultured society. It can be stated that they were a good substitute for the absence of economic journals.

\section{SOURCES}

Gaceta Economista, n. 1 and 5 (1861).

La España Moderna, n. 1-312 (1889-1914).

La Tribuna de los Economistas, n. 13 (1858).

Revista Contemporánea, n. 1-686 (1875-1907).

Revista de España, n. 1-596 (1868-1894).

Revista Europea, n. 1-319 (1874-1880).

Revista Nacional de Economía, n. 1 (1916).

\section{REFERENCES}

Albert, P. (1996): «Préface», in L. Marco (ed.), Les revues d'économie en France. Génese et actualité 1751-1994. Paris: L'Harmattan, pp. I-XXXII.

Albert, P. (1990): Histoire de la Presse. Paris: Presses universitaires de France.

Almenar, S. (1996): «Economic Thought in Spanish Periodical Publications of the 18th and 19th Centuries: An Introduction». History of Economic Ideas, IV (3), pp. 119-147.

Almenar, S. (2000): «El desarrollo del pensamiento económico clásico en España», in E. Fuentes Quintana (ed.), Economía y economistas españoles, 4. La economía clásica. Barcelona: Galaxia Gutenberg, pp. 7-92.

Almenar, S. (2005): «Chair, Tribune and Seat: Spanish Economists in Parliament (18441923). An Exploration», in M. Augello, and M. Guidi (eds), Economists in Parliament in the Liberal Age (1848-1920). Aldershot: Ashgate, pp. 75-102. 
Almenar, S., and Lombart, V. (2001): «Spanish Societies, Academies and Economic Debating Societies», in M. Augello, and M. Guidi (eds), The Spread of Political Economy and the Professionalisation of Economists. London: Routledge, pp. 109-125.

Asun, R. (1979): El proyecto cultural de La España Moderna y la literatura. PhD Thesis, Barcelona: Universidad de Barcelona.

Augello, M. M. (1992): «La nascita di una professione accademica: Gli economisti italiani post-unitari (1860-1900). Un' analisis quantitativa». Quaderni di Storia dell' Economia Politica, 10 (3), pp. 3-39.

Augello, M. M. (1994): «L'evoluzione della letteratura economica in Italia: 1861-1900. Una analisi storico-quantitativa». Il pensiero economico italiano, 2 (1), pp. 7-36.

Augello, M. M. (1995): "Il ruolo dei periodici nell'economia politica italiana della seconda metà dell' Ottocento». Il pensiero economico italiano, 3 (2), pp. ix-lxxiii.

Augello, M.; Bianchini, M., and Guidi, M. (eds) (1996): Le Riviste di Economia in Italia (1700-1900). Dai Giornali Scientifico-Letterari ai Periodici Specialistici. Milano: Franco Angeli.

Augello, M., and Guidi, M. (1996): «The Emergence of Economic Periodical Literature in Italy (1750-1900)». History of Economic Ideas, 4 (3), pp. 15-62.

Ballantyne, M. (1990): «Índice de la Revista de España bajo la dirección de Galdós». Hispania, 73 (2), pp. 332-344.

BARUCCI, P. (1988): «La cattedra e l' autonomia della scienza economica: una riflessione», in M. Augello, M. Bianchini, G. Gioli, and P. Roggi (eds), Le Cattedre di Economia Politica in Italia. La Diffusione di Una Disciplina "Sospetta" (1750-1900). Milano: Franco Angeli, pp. 25-30.

Bianchini, M. (ed.) (1996): Political Economy in European Periodicals, 1750-1900. Special issue of History of Economic Ideas, 4, 3.

BINI, P. (ed.) (2004): I Novant'anni Della Rivista di Politica Economica (1911-2000). Teorie Economiche, Scelte Politiche e Cultura D'impresa Nell'italia del Novecento. Special issue of the Rivista di Politica Economica.

Cardoso, J.L., and Lluch, E. (1999): "Las teorías económicas contempladas a través de una óptica nacional», in E. Fuentes Quintana (ed.), Economía y Economistas Españoles, 1. Una Introducción al Pensamiento Económico. Barcelona: Galaxia Gutenberg, pp. 477-484.

Coats, A. W. (1971): «The Role of Scholarly Journals in the History of Economics». Journal of Economic Literature, 9 (1), pp. 29-44.

Conts, A. W. (1991): «The Learned Journals in the Development of Economics and the Economics Profession. The British Case». Economic Notes by Monte dei Paschi di Siena, 20 (1), pp. 181-188.

Coats, A. W. (1996): «British Nineteenth Century Economic Periodicals». History of Economic Ideas, 4 (3), pp. 63-76.

Comín, F. (2001): «Las modestas realizaciones de la nueva política económica intervencionista de la Restauración», in E. Fuentes Quintana (ed.), Economía y Economistas Españoles 5. Las Críticas a la Economía Clásica. Barcelona: Galaxia Gutenberg, pp. 197-238.

Costa, P. (1996): «La «cultura delle riviste» e i saperi specialistici: A proposito di storia del pensiero economico e juridico». Il Pensiero Economico Italiano, 4 (2), pp. 123-129.

De Broglie, D. (1979): Histoire Politique de la Revue des Deux Mondes de 1829 à 1979. Paris: Perrin.

Delgado, I. (1983): La Revista Europea y su Significado Filosófico. Salamanca: Ediciones Universidad de Salamanca. 
Dendle, B. J. (1970): «Albareda, galdós y la revista de españa», in C. Lida, and I. Zavala (eds), La Revolución de 1868: Historia, Pensamiento, Literatura. New York: Las Américas, pp. 362-375.

Edwards, R. D. (1993): The Pursuit of Reason: The Economist, 1843-1993. London: Hamish Hamilton.

Estapé, F. (1990): Introducción al Pensamiento Económico. Una Perspectiva Española. Madrid: Espasa Calpe.

FAUCCI, R. (1996): «L'economia politica nelle riviste: uno sguardo d'assieme». Il pensiero Economico Italiano, 4 (2), pp. 115-122.

Fetter, F. W. (1965): «Economic Controversy in the British Reviews, 1802-1850». Economica 32, pp. 424-437.

Fetter, F. W. (1980): The Economists in Parliament, 1780-1868. Durham, NC: Duke University Press.

GuÉRIN, S. (1991): La Presse Economique et Financière. Paris: C.F.P.J.

Hagemann, H. (1991): «Learned Journals and the Professionalization of Economics: The German Language Area». Economic Notes by Monte dei Paschi di Siena, 20 (1), pp. 33-57.

Hagemann, H. (1996): "German Economic Journals and Economic Debates in the Nineteenth Century». History of Economic Ideas, 4 (3), pp. 77-102.

Hagemann, H. (2001): «The verein für sozialpolitik from its Foundation Until World War I», in M. Augello, and M. Guidi (eds), The Spread of Political Economy and the Professionalisation of Economists. Economic Societies in Europe, America and Japan in the Nineteenth Century. London: Routledge, pp. 152-175.

Henderson, J. P. (1996): «Emerging Learned Societies. Economic Ideas in Context». Journal of the History of Economic Thought, 18, pp. 186-206.

Henno, J. (1993): La Presse Économique et Financière. Paris: Presses universitaires de France.

Laurent, E., and Marco, L. (1990): Le Journal Des Economistes 1841-1940: Historique et Tables Résumées. Paris: A.N.D.E.S.E.

Laurent, E., and Marco, L. (1996): "Le journal des économistes, ou l'apologie du libéralisme», in L. Marco (ed.), Les Revues D'économie en France. Génese et Actualité 1751-1994. Paris: L’Harmattan, pp. 79-120.

Le Van-Lemesle, L. (1996): «Nineteenth Century Economic Reviews in France». History of Economic Ideas, 4 (3), pp. 103-118.

Lutfalla, M. (1972): «Aux origines du liberalisme économique en France: le Journal des économistes». Revue Economique et Sociale, 4, pp. 494-517.

Marco, L. (1990): «Les premières revues consacrées à l’ Économie industrielle en France (1898-1940): essai prémature ou reflet d'une tradition?». Revue D'économie Industrielle, 54 (4), 113-129.

MARCo, L. (1995): "Les économistes français et leurs revues, des physiocrates aux économètres (1751-1981)». La Revues des Revues, 20 (2), pp 77-89.

Marco, L. (ed.) (1996): Les Revues D'économie en France. Génese et Actualité 1751-1994. Paris: L'Harmattan.

Martorell, M. (2011): José Sánchez Guerra. Un hombre de Honor (1859-1935). Madrid: Marcial Pons.

Menéndez Pelayo, M. (1999): Epistolario. Madrid: Fundación Universitaria Española y Caja Cantabria.

Neumark, F. (1984): «Hundert jahre «Finanzarchiv»». Finanzarchiv, Neue Folge, 42, pp. 385-406.

Olascoaga, R. (1896): Estado Actual de los Estudios Económicos en España. Madrid: Victoriano Suárez. 
PAZ, R. (1950): Revista Contemporánea (Madrid, 1875-1907). Madrid: Instituto Cervantes. Perlman, M. (1991): «On the Editing of American Economics Journals: Some Comments on the Earliest Journals and the Lessons suggested». Economic Notes by Monte dei Paschi di Siena, 20 (1), pp. 159-172.

Pizarroso, A. (1994): Historia de la Prensa. Madrid: Centro de Estudios Ramón Areces.

Roman, R. (2003): La Escuela Economista Española. Sevilla: Universidad de Sevilla.

SáncheZ, A., and Malo, J.L. (2001): "Álbum», in E. Fuentes Quintana (ed.), Economía y Economistas Españoles, 5. Las Críticas a la Economía Clásica. Barcelona: Galaxia Gutenberg, pp. i-lxiii.

SERrano, J. M. (2001): «Escuelas e ideas en la Restauración decimonónica», in E. Fuentes Quintana (ed.), Economía y Economistas Españoles 5. Las Críticas a la Economía Clásica. Barcelona: Galaxia Gutenberg, pp. 129-150.

Stigler, G. J. (1965): Statistical Studies in the History of Economics. Chicago: University of Chicago Press.

Stigler, G. J.; Stigler, S. M., and Friedland, C. (1995): «The Journals of Economics». The Journal of Political Economy, 103 (2), pp. 331-359.

Ten, A., and Celi, M. (1996): Catálogo de las Revistas Científicas y Técnicas Publicadas en España Durante el Siglo XIX. Valencia: Universitat de València - CSIC.

TRIBE, K. (1992): «The Economic Journal and British Economics, 1891-1940». History of the Human Sciences, 5 (4), pp. 33-58.

Yeves, J. A. (2002): La España Moderna. Catálogo de la Editorial. Índice de las Revistas. Madrid: Libris.

Yeves, J. A. (2012): "Prólogo», in M. A. Ayala, and J. Ramos (eds), Rafael Altamira, José Lázaro Galdiano y La España Moderna (1889-1905). Alicante: Universidad de Alicante, pp. 9-11.

Zavala, I. M. (1972): Románticos y Socialistas. Prensa Española del XIX. Madrid: Siglo XXI. 